The Soviet Union and its Geographical Problems 
Also by Roy E. H. Mellor
Geography of the USSR
Sowjetunion
Comecon - Challenge to the West
Eastern Europe : A Geography of the Comecon Countries
The Two Germanies : A Modern Geography
Europe: A Geographical Survey of the Continent (with E. A. Smith) 


\section{The Soviet Union and its Geographical Problems}

Roy E. H. Mellor

Department of Geography, University of Aberdeen 
() Roy E. H. Mellor 1982

All rights reserved. No part of this publication may be reproduced or transmitted, in any form or by any means, without permission.

First published 1982 by

THE MACMILLAN PRESS LTD

London and Basingstoke

Companies and representatives throughout the world

ISBN 978-0-333-27663-1 ISBN 978-1-349-16739-5 (eBook)

DOI 10.1007/978-1-349-16739-5

Typeset by

CAMBRIAN TYPESETTERS

Farnborough, Hants

The paperback edition of this book is sold subject to the condition that it shall not, by way of trade or otherwise, be lent, resold, hired out, or otherwise circulated without the publisher's prior consent, in any form of binding or cover other than that in which it is published and without a similar condition including this condition being imposed on the subsequent purchaser. 
To H. K. M. 


\section{Contents}

Introduction $\quad$ xi

List of Maps xiii

List of Tables xiv

1 The Soviet Milieu 1

1.1 The major landscape zones $\quad 8$

$\begin{array}{lr}\text { The tundra } & 8\end{array}$

$\begin{array}{ll}\text { The tayga } & 10\end{array}$

The mixed forests 13

The steppe 14

The desert $\quad 15$

The Transcaucasian lowlands $\quad 16$

The mountains $\quad 16$

$\begin{array}{lll}1.2 & \text { Environment and the Soviet milieu } & 17\end{array}$

Conservation and pollution problems in the
Soviet setting

1.3 Where to follow up this chapter 23

2 The Soviet State - its Territorial Origins and its Internal Organisation

2.1 Territorial growth - the beginnings 25

2.2 Territorial growth from the eighteenth century 28

2.3 Territorial problems after the Revolution of $1917 \quad 29$

2.4 Territorial gains after the Second World War 30

2.5 Internal territorial problems 32

2.6 The territorial-administrative organisation 34

2.7 Economic regionalisation 38

2.8 Where to follow up this chapter 45 
viii

3 The Soviet People 46

3.1 The ethnic problem 50

3.2 Geographical distribution of population 57

3.3 The role of migration in the population pattern $\quad 66$

3.4 Where to follow up this chapter 70

4 Settlements - Where Soviet People Live 71

4.1 The village 71

4.2 The town 73

4.3 Where to follow up this chapter 83

5 Soviet Agriculture $\quad 84$

5.1 Where to follow up this chapter 101

6 Soviet Industry - The Resource Base 102

6.1 Energy resources 105

6.2 Spacial distribution of the main energy resources 107

Coal 107

Oil $\quad 110$

Electricity 113

6.3 Metallic minerals 116

6.4 Iron and the ferrous metals 118

6.5 Non-ferrous metals 119

6.6 Minerals for the chemicals industry 120

6.7 Where to follow up this chapter 121

7 Soviet Industry - The Major Branches 122

$\begin{array}{lll}7.1 & \text { The metallurgical industries } & 128\end{array}$

7.2 Non-ferrous metallurgy 132

7.3 Fngineering 134

$\begin{array}{lll}7.4 & \text { The chemicals industry } & 138\end{array}$

7.5 Textile industries 141

7.6 Where to follow up this chapter 144

8 Transport - Holding the Soviet Economy Together 146

8.1 Railways 152

8.2 Inland waterways $\quad 159$

8.3 Sea-going shipping 162

8.4 Road transport $\quad 165$

$\begin{array}{lll}8.5 & \text { Pipelines } & 167\end{array}$

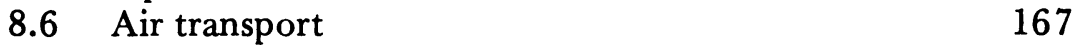


8.7 Postal- and telecommunications 168

$\begin{array}{ll}\text { 8.8 Where to follow up this chapter } & 169\end{array}$

9 The Soviet Union and the World since $1945 \quad 170$

9.1 The Soviet trading pattern 173

9.2 Changing spatial patterns in the USSR 180

9.3 The Socialist bloc in the world 183

9.4 The Soviet dilemma in the Third World 184

9.5 The Soviet strategic position 187

$\begin{array}{lll}9.6 & \text { Towards the year } 2000 & 192\end{array}$

9.7 Where to follow up this chapter 194

Bibliography $\quad 197$

Index 201 


\section{Introduction}

This review of the geography of the Soviet Union is designed for students and others seeking an introduction to this, the world's largest compact political territory, encompassing one-sixth of the land surface of our planet. In assessing the achievements or failures of the USSR or in making comparisons between it and other powers, it is essential to appreciate the real nature of the environment, both in terms of its physical setting and its time-space matrix, in which Soviet citizens live out their lives. In so many respects the Soviet milieu is bedevilled by the harshness of the physical world around it and by the sheer 'embarrassment of space'.

The study is built around nine chapters, each devoted to a specific thematic topic in the geography of the country as a whole. In the contemporary setting it is felt important to concentrate attention on an overview of the territory as a whole rather than follow the conventional and perhaps now rather dated plan of a brief general review and then a region-by-region survey. For the majority of people seeking a general overview of the Soviet Union, the coherence of the whole is most meaningful.

The Soviet Union lies upon a threshold of rapid change. The prewar and early post-war economy was built along lines that resembled nineteenth-century industrialisation in Western Europe. Now, having increasingly entered the arena of world trade and technology, a new sophistication is being added by the turbulent effort to keep abreast of the accelerating technological change brought about by the age of the silicon chip that has dawned in the Western world. At the same time, patterns of demographic change pose challenges in the supply of labour and in internal political forces through the shift in balance between the major ethnic groups. As a new 'window on the West' 
has opened, consumer pressures for a bigger slice of the national cake have also developed.

There has also been the relaxation of the tight encapsulation of Stalinist days, not only in the attitude to the world at large, but also as the Council for Mutual Economic Assistance (Comecon) has evolved. It is now unreal to consider the geography of the Soviet Union without reference to the country's role as the core of this group of socialist nations acting in concert for mutual economic advantage. This is examined in particular in the final chapter, where an assessment of the world position of the Soviet Union is attempted. Such a review represents one 'model' of the world scene; readers may care to construct others for themselves.

The text owes much to the useful comments made by my colleague, E. Alistair Smith. The manuscript was typed by Jane Calder, the maps prepared by Laurie McLean and Philip Glennie, while Sheila Bain helped in the collection of material. My wife read the proofs, prepared the index and kept the 'inner man' in good fettle while writing. To everybody I am most grateful. I must also record the pleasure of working with Derick Mirfin, John Winckler, Keith Povey and Steven Kennedy, 'Macmillan's men'.

Old Aberdeen

Roy E. H. Mellor

June 1981 


\section{List of Maps}

1.1 The world position of the Soviet Union 2

1.2 Terrain types 5

1.3 Major natural landscapes 9

2.1 The growth of Russia 27

2.2 The western boundaries of the Soviet Union 31

2.3 Administrative-territorial structure 35

2.4 Boundaries of planning regions 40

3.1 Age and sex structure of the Soviet Union, $1970 \quad 48$

3.2 The ethnic map of the USSR 52

3.3 Population distribution in the USSR 58

4.1 The distribution of Soviet urban population 75

5.1 The physical conditions of farming 86

5.2 Types of farming in the USSR 94

6.1 Mineral deposits in the USSR 103

6.2 Energy resources in the USSR 106

6.3 Electricity supply in the USSR 114

7.1 The distribution of industry in the USSR 142

8.1 The Soviet concept of a 'unified transport system' 147

8.2 The Soviet railway system 153

9.1 The world distribution of Soviet aid 179 


\section{List of Tables}

3.1 Growth of population

3.2 Births, deaths and natural increase by republics per 1,000 of the population

3.3 Ethnic structure of the USSR

4.1 Settlements of town type - criteria for definition in selected republics

6.1 Soviet mineral production and its world share 104

7.1 Position of the USSR in world industrial production 144

8.1 Division of transport effort between the media 148

8.2 Division of originating goods and passengers among the transport media

9.1 Soviet foreign trade (in million roubles at contemporary prices) 